\title{
The Effects of Training on Sustainable Development Practices in Higher Education: The case of Ibn Tofail University in Kénitra (Morocco)
}

\author{
MUSTAPHA KOUZER*, ABDELAZIZ CHAOUCH, EL MAHJOUB AOUANE, KELTOUM \\ RAHALI \\ Laboratory of Agrophysiology, Biotechnology, Environment and Quality, Faculty of Sciences, \\ Ibn Tofail University in Kénitra \\ Kénitra, 14000 \\ MOROCCO \\ NOURA ETTAHIR, ABDERRAZZAK KHOHMIMIDI, ABDELLATIF ELOUALI, ADIL AMMAR \\ Higher School of Technology of Salé \\ Mohammed V University in Rabat \\ BP, 227 Salé, 11000 \\ MOROCCO
}

\begin{abstract}
The objective of this article is to study the existing relationship between training and the integration of Sustainable Development (SD) practices in the Moroccan University. The issue at stake is to verify whether the training provided at the level of higher education institutions responds to the various worldwide challenges. In order to respond to the difficulties that impact the higher education model, Moroccan universities are invited to rethink their various approaches so that they can respond to the economic, social, societal and environmental constraints which are constantly evolving. Therefore, these universities must align themselves with the major challenges facing education today[1].

The empirical research method used in this quantitative study is a Likert's scale based questionnaire. The investigation was carried out on a sample of 134 teachers-researchers of Ibn Tofail University of Kénitra (ITUK) (Morocco). The investigated sample population was surveyed during the time period lasting from February the 1 st to May the 31th, 2021.

The analysis conducted regarding the results of the ANOVA of the variables reveals that the pedagogical approaches, curriculum and teaching methods are significant except for the teaching activities which display a value of 0.280 higher than the recommended threshold.

Consequently, training in higher education can contribute to forging attitudes in the future in line with SD's requirements by relying on pedagogical approaches. Hence, the University through training should contribute to a sustainable society in order to meet the 17 SD Goals which require that by 2030 all students should have the knowledge, skills and attitudes necessary to promote sustainable development.

The results of this research will contribute to the development of new training curricula that meet the requirements of the various SD objectives. We have focused our research on the ITU Kénitra, we believe that our approach will serve as a basis to develop other cases of Moroccan universities to have an overall vision of training curricula converging towards the practices of SD at the Moroccan national level and for a better contribution in the new 2035 nationwide development model[2].
\end{abstract}

Key-Words: - Training, Sustainable Development, Sustainable Development practices, Higher Education, Ibn Tofail University Kénitra, Morocco

Received: February 27, 2021. Revised: August 7, 2021. Accepted: August 13, 2021. Published: September 2, 2021.

\section{Introduction}

One of the main missions of the education and training sector is the preparation of future upcoming generations to face the major challenges of today and tomorrow. Higher education is mandated to perpetuate the process of development in general and Sustainable Development (SD) in particular by working towards the implementation of SD practices 
in the university that has become a powerful engine of innovation and economic, social and cultural changes.

Training provides the knowledge, skills, attitudes and values needed to build a sustainable future[3].Thus, several challenges have been taken up in order to steer the training curricula of higher education institutions towards strengthening innovative practices for learning, research and knowledge development.

Several research papers have focused on the subject, for instance some works emphasized the driving role of the university in using new technologies in the educational process in order to transform the forms of students' learning patterns and attitudes, especially when it comes to learning that must converge towards the acquisition of new SD practices[4].

At the same time point out that education is also seen as one of the main drivers of economic growth. We share this view in the sense that economic growth is a key component of SD[5].

Most research on SD in Moroccan universities has been limited to perceptions and not to practices[6]. We therefore consider that our study focusing on the Moroccan university will be of great benefit because it will allow us:

- To have the opportunity to analyze the curriculum, activities, methods and approaches used by university teachers for this purpose.

- To assess SD actions integration and implementation degree in higher education institutions.

In addition, by committing to the 17 SD Goals[7], the university is required to ensure that all students possess the necessary knowledge and skills to promote the SD objectives through their training and academic curricula.

In the same perspective, Ibn Tofail University of Kénitra (ITUK) has been involved and committed to social and societal responsibility through the quality of its training, research, teaching, knowledge transfer and governance. Moreover, for the third consecutive year, (ITUK) has been distinguished in the prestigious universities' international ranking "Times Higher Education Impact Ranking 2021"[8] where more than 1115 universities participated in the 2021 edition, representing 94 countries. Another distinction of ITUK is the "Affordable and Clean Energy" [9] objective, where it was ranked 9th in the world $\left(45^{\text {th }}\right.$ rank in 2020$)$, first at national scale, Africa and the Arab countries.

The University is currently at the heart of our country's social project, because of the missions it undertakes in the training of future citizens, the achievement of the National Strategy for Sustainable Development (NSSD) objectives and, the guarantee of the right to education for all. It is in this regard at the centre of national priorities and concerns. It is a catalyst for the knowledge economy and must therefore ensure training by producing knowledge that is useful not only for the labour market, but above all for the needs of a qualified workforce and for the personal development of both women and men. It is widely admitted that training through education is a sine qua non for countries development. It is, according to the World Declaration on Education for All (1990), "an indispensable, if not sufficient, condition for the development of the individual and society" [10] as it can help "improve global security, health, prosperity and ecological balance, while promoting social, economic and cultural progress, tolerance and international cooperation".

In this respect, education plays the role of a lever for SD objectives, considered as a key element in rethinking the world in a different way, developing new ways of understanding it, and developing a new way of acting, according to Nelson Mandela's famous saying "Education is the most powerful weapon you can use to change the world"[11].

In November 2014, UNESCO and the Japanese government hosted the World Conference on Education for SD: "Learning Today for Sustainable Development" [12]. Therefore, the university plays an important role through "research, teaching and practice, higher education has a key role to play in achieving sustainable development" [13]. Indeed, sustainable higher education is not limited to 'simply' adding SD to existing curricula structures, but should focus on fundamental changes in thinking, research and teaching methods. In other words, SD is not an additional subject to be integrated into the curriculum, but a starting point for a new look at curricula, pedagogy, organization, policy and lifestyle[14].

In this respect, the subject has always attracted the attention of scientists, academics, industrialists, politicians and society in general, as one only has to review the literature on academic, scientific and social issues to note the importance of this approach to SD in academia, also in the light of the social and societal changes that the world is currently experiencing.

The term sustainable development (SD) is differently defined by various authors. Several questions are currently raised, without clear answers, about its signification or definition. And, above all, the implication of SD in development theory and practice [15]. 
Development in this sense aims to achieve social progress, environmental balance and economic growth [16],[17].

In the same perspective, and as underlined by Gro Harlem Brundtland in her report "Our Common Future" [18], the World Commission on Environment and Development (WCED) has addressed the younger generations directly and in a special way. In this regard, WCED emphasized the crucial role that teachers and scientists around the world must play in spreading the message to the younger generation. We hereby, remember this excerpt aimed at educational institutions and clarifying their role in the development of a better world: "We appeal to citizens' groups, non-governmental organizations, educational institutions and the scientific community. In the past, they have all played an indispensable role in public education and policy change. They will now play an equally crucial role in guiding the world on a path of development that is sustainable, laying the foundations for all our future"[16], [19].

In this respect, SD is automatically linked to education and training for SD. According to Arnaud Diemer [20] SD cannot be discussed without raising the educational issue, the way of thinking at the pedagogical level, and how knowledge and knowhow, and even a new model of life in society, can be passed on to future generations.

Moreover, at the Nagoya Summit [20] a declaration called for urgent action to further strengthen and intensify education for SD to enable present generations to meet their needs, while enabling future generations to meet theirs, through a balanced and integrated approach to the economic, social and environmental dimensions of SD.

Therefore, and in order to understand this topic, we present in the following sections our empirical investigation approach.

\section{Methodology}

In a context marked by debates and controversies, this paper examines the roles of training in higher education SD practices, in order to open up a reflection window on how to achieve effective SD practices in the Moroccan academic institutions.

We have adopted an empirical method based on a quantitative study essentially using a questionnaire as a data collection tool. The questionnaire's elaboration took into account the curricula's teachers degree of satisfaction with regard to the (course and content of the teaching programs dedicated to $\mathrm{SD}$, as well as the inter-departmental collaboration in training programs related to $\mathrm{SD}$ ).
In developing the questionnaire's components, we have taken into consideration the teachers' opinions on the methods and pedagogical approaches used in the teaching process.

The aim is to present the results of an investigation that was realized in ITUK, an academic entity that possess numerous considerable assets and has achieved a prestigious performance represented by international community recognition, , besides the commitment this university to social and environmental responsibility. The survey lasted three (03) months starting the first February and ending on April the 30th (2021).

\subsection{The target population}

ITUK is a Moroccan public university located in the Kénitra city (Morocco's western region). Founded in 1989, it offers training courses leading to officially recognized higher education diplomas, such as prebachelor's degrees (i.e. certificates, diplomas, and associated diplomas or basic diplomas) in several study fields. It is keen to assert its positioning and display its values which allow it to embody a Green and Open University identity [21].

ITUK holds several branches and institutions. It is constituted of five faculties, five schools and a Sports' Professions Higher Institute. Besides, the university has continued to grow and develop both in terms of training provided, infrastructure and human resources as shown in the following table.

Table 1: The different entities of ITUK

\begin{tabular}{|c|c|}
\hline $\begin{array}{l}\text { Centers of } \\
\text { expertise }\end{array}$ & Establishments \\
\hline $\begin{array}{l}\text { Science and } \\
\text { Techniques }\end{array}$ & $\begin{array}{l}\text { - Faculty of Science } \\
\text { - High School of Technology } \\
\text { - National School of Chemistry }\end{array}$ \\
\hline $\begin{array}{l}\text { Engineering } \\
\text { Sciences }\end{array}$ & - National School of Applied Sciences \\
\hline $\begin{array}{l}\text { Humanities } \\
\text { and Social } \\
\text { Sciences }\end{array}$ & - Institute of Sports Professions \\
\hline $\begin{array}{l}\text { Law, } \\
\text { Economics } \\
\text { and } \\
\text { Management } \\
\text { Sciences } \\
\end{array}$ & $\begin{array}{l}\text { - Faculty of Law and Political Sciences } \\
\text { - Faculty of Economics and } \\
\text { Management } \\
\text { - National School of Business and } \\
\text { Management }\end{array}$ \\
\hline $\begin{array}{l}\text { Humanities } \\
\text { and Social } \\
\text { Sciences }\end{array}$ & $\begin{array}{l}\text { - Faculty of Humanities and Social } \\
\text { Sciences } \\
\text { - Faculty of Languages, Literature and } \\
\text { Arts }\end{array}$ \\
\hline $\begin{array}{l}\text { Education } \\
\text { Science }\end{array}$ & $\begin{array}{l}\text { - Higher School of Education and } \\
\text { Training }\end{array}$ \\
\hline
\end{tabular}

\subsection{Study tools}

To carry out this investigation, we have proceeded to the elaboration of different headings that constitute 
our questionnaire in order to grasp the well-founded of the various SD practices in the training within the university.

The data collection tool used is the questionnaire, which is the most appropriate quantitative data gathering tool yet numerous authors like [6], [22] have been interested in the study of different quantitative tools for the diagnosis and evaluation of SD at the level of higher education institutions.

These studies all tend to examine and analyze the efforts made to determine SD integration level in higher education, which led us to contextualize this type of investigation at the Moroccan scale.

We have conducted our questionnaire's pre-test among a sample of 10 university professors, from two different institutions. These professors perform many tasks as managers and heads of departments effectively active in SD field. The pre-test allowed us to check the questionnaires' fluidity and therefore improve its final version by integrating all the necessary components.

\subsection{Questionnaire's variables components}

These components can be summarized as follows:

- The integration of SD as modules or module elements in the teaching specifications;

- The commitment of the university's institutions to SD;

- The curriculum and teaching acts;

- The pedagogical approaches used in teaching;

- The development of values and skills of university students.

We have adopted the quantitative method by formulating 54 items among the set of items previously identified in the literature review mobilizing a Five-Level Likert's scale [23].

\subsection{Sampling}

We have based our study on a 400 ITUK teachersresearchers sample, 134 of whom have effectively participated in the survey. The size of the sample is thus representative, since it exceeds one-seventh (1/7) of the parent population of 620 teachers [24].

\subsection{Processing phase: Exploratory Factor Analysis}

In order to construct the model related to training and its implications on SD practices, several phases are elementary. In a first step, it is essential to verify the content validity of the training measurement scale of the two variables: an Explanatory variable that is represented as "training" and an explanatory variable identified as " SD practices".
In order to construct our measurement scale, we have first determined the four dimensions of the variable "Training", namely curriculum, approaches, teaching methods and teaching activities. Then, we checked the prerequisites and used Principal Component Analysis (PCA) to extract the appropriate number of factors. Furthermore, we have performed the Varimax rotation, interpreted the factors and assessed the content validity of the training measurement scale. The aim of content validity tests is to check whether the various questionnaire items represent the concept under examination [25] before they are cleaned up.

The factor structure and psychometric qualities of the training and SD practices scale were analyzed using SPSS 23 software, and the data were subjected to Principal Component Analysis (PCA) with Varimax rotation in order to test the dimensionality of the construct.

The PCA analysis of the four dimensions of training is considered desirable in order to reduce the number of items and retain only those that allow the phenomenon to be characterized, in particular to identify the main factors (Costello and Osborne, 2005; Fabrigar et al.1999; Roussel, 1996). The correlation matrix was calculated from the raw data (individual scores on the different variables). The purging of items deemed unsatisfactory was carried out based on the following elimination parameters: rejection of items with a factor score below 0.3 and those with a high factor score on several factors [26]. The internal consistency reliability of the scale and its different dimensions was assessed by analyzing Cronbach's alpha.

We have equally realized the analysis by multiple linear regression in order to study the causality between a dependent variable $\mathrm{Y}$ and $\mathrm{K}$ and other independent variables $(\mathrm{X} 1, \mathrm{X} 2, \ldots . \mathrm{Xk})$. Thus the algebraic model developed is the following:

$$
\text { yi }=\beta 0+\beta 1 x 1 i+\beta 2 x 2 i+---+\beta p x+\varepsilon i
$$

In our case, $\mathrm{Y}=\mathrm{SD}$ practices; $\mathrm{X} 1=$ Curriculum; $\mathrm{X} 2=$ =Pedagogical approaches; $\mathrm{X} 3=$ Pedagogical methods; $\mathrm{X} 4=$ Teaching activities.

\subsection{The multiple linear regression analysis process:}

- Estimation of the regression coefficients $\beta 0$, $\beta 1, \beta 2 \mathrm{i}+\ldots+\beta \mathrm{p}$ (ordinary least squares (OLS) method).

- Quality model measure R2 (coefficient of determination); $\mathrm{R} 2=\mathrm{SC}$ reg/SCtot; $0<\mathrm{R} 2<1$.

- Check whether the marginal contribution of each $\mathrm{Xj}$ to the explanation of $\mathrm{Y}$ is significant (Student's test). 
- Choice of the optimal model and discussion of the results according to the literature.

\subsection{Hypotheses formulation}

H1: The curriculum has a significant effect on SD practices.

$\mathrm{H} 2$ : Pedagogical approaches have a significant effect on sustainable development practices.

H3: The more diversified the teaching methods, the more they impact SD practices.

$\mathrm{H} 4$ : Teaching activities have a direct impact on SD practices.

At the end of the methodological approach adopted, our investigation revealed qualitative characteristics such as the nature of the institutions and their departments, which we present below before proceeding to discuss our results.

\section{Results and discussion}

The collected results allowed us to highlight the SD practices. We worked then on 4 dimensions of training (explanatory variable) which are:

1 Curriculum.

2 Pedagogical approaches.

3 Teaching methods.

4 Teaching activities.

As for SD practices (variable to be explained), it is represented by:

1 The university's vision and actions towards SD.

2 Types of collaboration favoring sustainable development teaching.

3 The expertise and willingness of ITUK teaching staff to participate.

With regard to the survey's participation rate of the institutions, as well as the departments involved, we present the data collected in this graphic:

\section{UITK institutions}

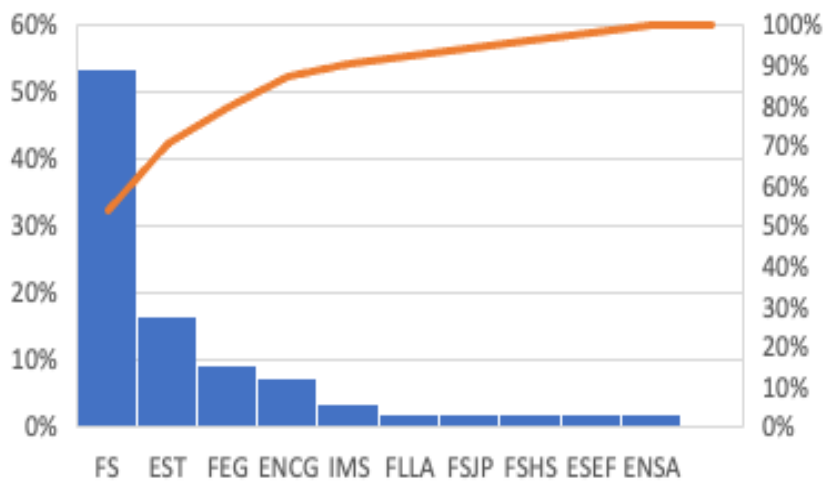

Fig. 1: ITUK's academic institutions.

The second graph prensents the various Institutional Departments at ITUK.

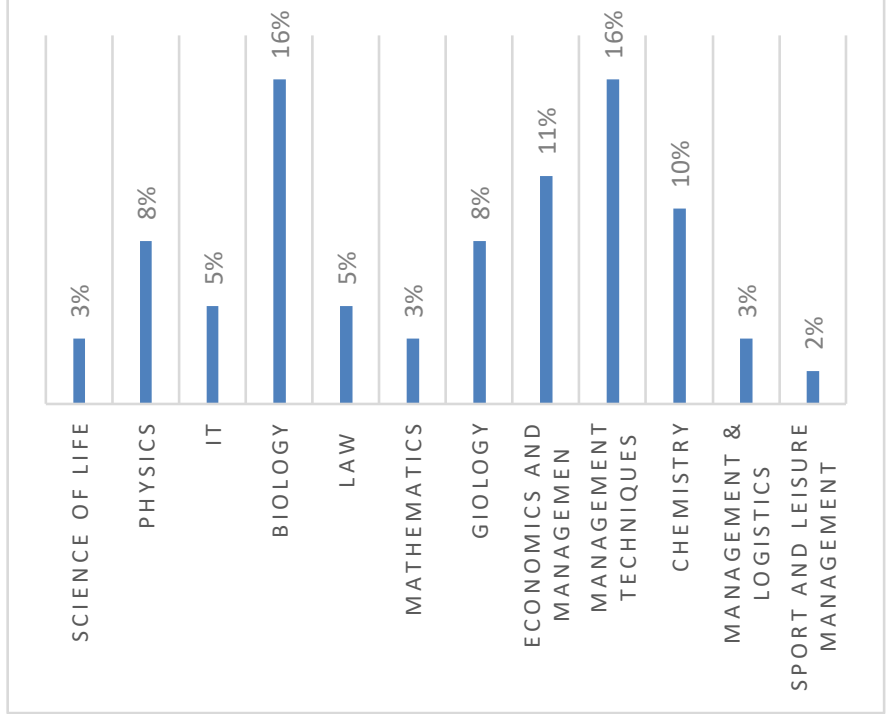

Fig. 2: Institutional departments at Ibn Tofaïl University

We have adopted an exploratory approach to determine the training dimensions and sustainable development practices and check for inter-item correlations. Then, we have measured the adequacy of the Kaiser-Meyer-Olkin (KMO) sampling and Bartlett's Sphericity Test, the results of which for each dimension are shown below:

\subsection{Training}

\subsubsection{The Curriculum component}

After checking the inter-item correlations of the Curriculum dimension of the Training variable, the results show that the KMO index is $0.649 \sim 0.7$ which is acceptable. We found that the data for this dimension are factorable. The result of Bartlett's test of sphericity are also significant as $p=0.000$ is below the threshold which is $<0.005$ (Table 2). The Chisquare is 71.082 and the $\mathrm{ddl}$ is 3 , which shows the existence of a good relationship between the different items that make up this dimension as a whole.

Table 2: KMO index and Bartlett's test of sphericity for the Curriculum dimension

\begin{tabular}{|l|l|r|}
\hline $\begin{array}{l}\text { Kaiser-Meyer-Olkin index for measuring } \\
\text { sampling quality. }\end{array}$ & 0.649 \\
\hline \multirow{3}{*}{ Bartlett Sphericity Test. } & Chi-Two approx. & 71.082 \\
\cline { 2 - 3 } & ddl & 0.000 \\
\cline { 2 - 3 } & Meaning & \\
\hline
\end{tabular}

In order to extract the appropriate number of factors for our dimension, we have first analyzed the total variance explained table and found that only one component has an eigenvalue higher than 1 . This factor alone explains $62.332 \%$ of the total variance of the analysis (Table 3 ). 
Table 3: Total explained variance of the dimension Curriculum

\begin{tabular}{|c|l|c|c|c|}
\hline \multicolumn{2}{|c|}{ Component } & $\mathbf{1}$ & $\mathbf{2}$ & $\mathbf{3}$ \\
\hline \multirow{2}{*}{$\begin{array}{c}\text { Initial Eigen } \\
\text { Values }\end{array}$} & Total & 1.87 & 0.656 & 0.474 \\
\cline { 2 - 5 } & $\%$ of the variance & 62.33 & 21.86 & 15.81 \\
\cline { 2 - 5 } & $\%$ Cumulated & 62.33 & 84.19 & 100 \\
\hline \multirow{2}{*}{$\begin{array}{c}\text { Sums } \\
\text { extracted } \\
\text { from the } \\
\text { load square }\end{array}$} & Total & 1.87 & & \\
\cline { 2 - 5 } & Variance \% & 62.33 & & \\
\cline { 2 - 5 } & $\%$ Cumulated & 62.33 & & \\
\hline
\end{tabular}

We observe that the three items values: (presence at departmental level of courses integrating SD topics, the hourly volume allocated to courses and the degree of inter-departmental collaboration in the teaching of SD programmes) are between 0.757 and 0.839 , which gives them an acceptable significance (Table 4).

Table 4: The Curriculum dimension components' matrix

\begin{tabular}{|c|c|c|}
\hline \multicolumn{2}{|r|}{ Items } & Component \\
\hline C1 & $\begin{array}{l}\text { Presence of courses at } \\
\text { departmental level integrating } \\
\text { Sustainable Development topics. }\end{array}$ & 0.770 \\
\hline $\mathrm{C} 2$ & $\begin{array}{l}\text { Large amount of time allocated to } \\
\text { these courses. }\end{array}$ & 0.757 \\
\hline $\mathrm{C} 3$ & $\begin{array}{l}\text { The degree of inter-departmental } \\
\text { collaboration in the teaching of } \\
\text { sustainable development } \\
\text { programmes. }\end{array}$ & 0.839 \\
\hline
\end{tabular}

In addition, we have calculated the Curriculum dimension Cronbach's alpha of the Training variable, which shows a value of 0.697 that is close to 0.7 . This qualifies it as excellent according to (Nanay, 1978).

Table 5: Reliability statistics

\begin{tabular}{|c|c|c|}
\hline $\begin{array}{c}\text { Cronbach's } \\
\text { Alpha }\end{array}$ & $\begin{array}{c}\text { Cronbach's Alpha based } \\
\text { on standardized items }\end{array}$ & $\begin{array}{c}\text { Number of } \\
\text { elements }\end{array}$ \\
\hline 0.697 & 0.697 & 3 \\
\hline
\end{tabular}

Therefore, we can say that for this scale composed of three items ( $\mathrm{C} 1, \mathrm{C} 2$ and $\mathrm{C} 3)$ we obtain a satisfactory internal consistency. We can indeed see that the consistency is maximized by keeping the three items, because if we discard one of them, the consistency will decrease. Thus, the Cronbach's Alpha value, in case of deletion of one item, is less than 0.697 .
Table 6: Total element statistics

\begin{tabular}{|c|c|c|c|c|c|}
\hline & $\begin{array}{c}\text { Scale } \\
\text { average } \\
\text { when an } \\
\text { item is } \\
\text { deleted }\end{array}$ & $\begin{array}{c}\text { Variance } \\
\text { of the } \\
\text { scale when } \\
\text { an } \\
\text { element is } \\
\text { deleted }\end{array}$ & $\begin{array}{c}\text { Full } \\
\text { correl } \\
\text { ation } \\
\text { of } \\
\text { correc } \\
\text { ted } \\
\text { items }\end{array}$ & $\begin{array}{c}\text { Squar } \\
\text { e of } \\
\text { the } \\
\text { multip } \\
\text { le } \\
\text { correl } \\
\text { ation }\end{array}$ & $\begin{array}{c}\text { Cronbach } \\
\text { 's Alpha } \\
\text { when the } \\
\text { item is } \\
\text { deleted }\end{array}$ \\
\hline C1 & 5.45 & 3.130 & 0.488 & 0.255 & 0.637 \\
\hline C2 & 4.84 & 3.170 & 0.473 & 0.237 & 0.655 \\
\hline C3 & 4.85 & 2.735 & 0.583 & 0.340 & 0.513 \\
\hline
\end{tabular}

\subsubsection{Dimension "Pedagogical approaches"}

With regard to the measurement of the "Pedagogical approaches" component, the results showed that the $\mathrm{KMO}$ index is 0.821 , which qualifies as excellent. This index shows us that the correlations between the items of the dimension are of good quality.

Table 7: KMO Index and Bartlett's test of the dimension "Pedagogical approaches

\begin{tabular}{|c|c|c|}
\hline \multicolumn{2}{|c|}{$\begin{array}{l}\text { Kaiser-Meyer-Olkin index for sampling } \\
\text { quality measuring. }\end{array}$} & 0.821 \\
\hline \multirow{2}{*}{$\begin{array}{l}\text { Bartlett's } \\
\text { Sphericity }\end{array}$} & Chi-Two approx. & 1066.793 \\
\hline & Ddl & 45 \\
\hline Test of & Meaning & 0.000 \\
\hline
\end{tabular}

The results of the exploratory analysis (Table 8 ) uncover two (02) factors according to the Kaiser's rule (1958), which leads to the selection of the number of factors whose eigenvalue is greater than or equal to 1 . Indeed, the first factor has an eigenvalue of 5.778 and represents 57.784 of the variance total and the second factor has an eigenvalue of 1.314 and explains $13.139 \%$ of the variance.

Table 8: Total variance explained for the dimension

"Pedagogical approaches" of the training variable

\begin{tabular}{|c|c|c|c|c|}
\hline \multicolumn{3}{|c|}{ Component } & 1 & 2 \\
\hline \multirow{3}{*}{$\begin{array}{l}\text { Initial } \\
\text { values }\end{array}$} & \multirow{3}{*}{ Eigen } & Total & 5.778 & 1.314 \\
\hline & & $\%$ of Variance & 57.784 & 13.14 \\
\hline & & $\%$ Cumulated & 57.784 & 70.92 \\
\hline \multirow{3}{*}{\multicolumn{2}{|c|}{$\begin{array}{l}\text { Sums extracted } \\
\text { from the load } \\
\text { square }\end{array}$}} & Total & 5.778 & \\
\hline & & $\%$ of Variance & 57.784 & \\
\hline & & $\%$ Cumulated & 57.784 & \\
\hline
\end{tabular}

With regard to the component matrix (Table 9), it demonstrates that the values of the 10 items representing the "Pedagogical approaches" dimension are between 0.596 and 0.869 , which gives them a so-called acceptable significance. 
Table 9: Component matrix of the "Pedagogical approaches" dimension of the training variable

\begin{tabular}{|l|l|l|}
\hline \multicolumn{2}{|c|}{ Items } & $\begin{array}{c}\text { Compo } \\
\text { nent 1 }\end{array}$ \\
\hline AP1 & $\begin{array}{l}\text { Systems thinking and complexity } \\
\text { management. }\end{array}$ & 0.770 \\
\hline AP2 & Critical thinking. & 0.740 \\
\hline AP3 & Anticipatory thinking. & 0.596 \\
APC1 & $\begin{array}{l}\text { The course draws on contextual } \\
\text { knowledge about the emergence of } \\
\text { SD and its main challenges. }\end{array}$ & 0.768 \\
\hline APC2 & $\begin{array}{l}\text { The course provides an opening to } \\
\text { other disciplines (adopting a global } \\
\text { and integrating vision and common } \\
\text { project) }\end{array}$ & 0.754 \\
\hline APC3 & $\begin{array}{l}\text { The course enables action to be } \\
\text { taken. }\end{array}$ & 0.769 \\
\hline APC4 & $\begin{array}{l}\text { The course makes use of Study } \\
\text { Skills. }\end{array}$ & 0.771 \\
\hline APC5 & The course uses Life Skills. & 0.824 \\
\hline APC6 & The course uses Civic Skills. & 0.869 \\
\hline APC7 & $\begin{array}{l}\text { The course uses Professional } \\
\text { Skills. }\end{array}$ & 0.710 \\
\hline
\end{tabular}

In addition, the Cronbach's alpha value for the dimension "Pedagogical approaches" is 0.915 , which is excellent. Thus, the internal consistency is strong. In fact, the items measure the pedagogical approaches well and in a consistent manner.

\subsubsection{Dimension "Teaching methods"}

The KMO index for the dimension of teaching methods is 0.771 which is $>0.5$. Therefore, the data for this dimension is factorable. The Bartlett's test of sphericity is significant since its value is $<0.005$. The Chi-square is presented with 2285.915 and the ddl with 231, which shows the existence of a good relationship between the different items that constitute this dimension as a whole.

Table 10: KMO index and Bartlett's test for the dimension "Teaching methods"

\begin{tabular}{|l|l|r|}
\hline \multicolumn{2}{|l|}{$\begin{array}{l}\text { Kaiser-Meyer-Olkin Index for sampling qualiyu } \\
\text { measurement. }\end{array}$} & 0.771 \\
\hline \multirow{3}{*}{ 1Bartlett's test of sphericity } & Chi-two approx. & 2285.915 \\
\cline { 2 - 3 } & Ddl & 231 \\
\cline { 2 - 3 } & Signification & 0.000 \\
\hline
\end{tabular}

We must then choose the number of factors to extract. To do this, we analyze the table of the total variance explained. In the second column of Table 11, we notice that the 5 factors have an eigenvalue $>1$, which we retain in full. The first factor alone explains $43.589 \%$ of the total variance of the 22 variables in the analysis, which we will retain, because it explains the said variance.
Table 11: Total variance explained for the dimension "Teaching methods"

\begin{tabular}{|c|c|c|c|c|c|c|}
\hline \multirow{2}{*}{$\begin{array}{c}\text { Comp } \\
\text { onent }\end{array}$} & \multicolumn{3}{|c|}{ Initial Eigen values } & \multicolumn{3}{c|}{$\begin{array}{c}\text { Sums extracted from } \\
\text { the load square }\end{array}$} \\
\cline { 2 - 7 } & Total & $\begin{array}{c}\text { \% of } \\
\text { Varian } \\
\text { ce }\end{array}$ & $\begin{array}{c}\text { \% } \\
\text { Cumul } \\
\text { ated }\end{array}$ & Total & $\begin{array}{c}\text { \% of } \\
\text { Varian } \\
\text { ce }\end{array}$ & $\begin{array}{c}\% \\
\text { Cumul } \\
\text { ated }\end{array}$ \\
\hline 1 & 8.718 & 43.589 & 43.589 & 8.718 & 43.589 & 43.589 \\
\hline 2 & 2.184 & 10.918 & 54.506 & 2.184 & & \\
\hline 3 & 1.384 & 6.921 & 61.427 & 1.384 & & \\
\hline 4 & 1.239 & 6.194 & 67.621 & 1.239 & & \\
\hline 5 & 1.045 & 5.223 & 72.843 & 1.045 & & \\
\hline
\end{tabular}

We can see from Table 12 that the values of the 22 items of the dimension "teaching methods" are between 0.430 and 0.832 , which gives them significance. The values of the 22 items in the "teaching methods" dimension are between 0.430 and 0.832, which gives them an acceptable significance.

Table 12: Matrix of components of the "Teaching methods" dimension"

\begin{tabular}{|c|c|c|}
\hline & Items & $\begin{array}{c}\text { Compo } \\
\text { nent } 1\end{array}$ \\
\hline TA1 & Learning to know (knowledge). & 0.560 \\
\hline TA2 & Learning to do (know-how). & 0.743 \\
\hline TA3 & Learning to be. & 0.742 \\
\hline TA4 & Learning to live together. & 0.557 \\
\hline TA5 & $\begin{array}{l}\text { Learning to become, learning to } \\
\text { transform oneself and society. }\end{array}$ & 0.662 \\
\hline $\mathrm{AC} 1$ & The course has a social aspect. & 0.532 \\
\hline $\mathrm{AC} 2$ & The course has an economic aspect. & 0.474 \\
\hline $\mathrm{AC} 3$ & $\begin{array}{l}\text { The course uses training content } \\
\text { tailored to environmental protection } \\
\text { requirements. }\end{array}$ & 0.635 \\
\hline DV1 & $\begin{array}{l}\text { Solidarity (present and future } \\
\text { generations). }\end{array}$ & 0.762 \\
\hline DV2 & Responsibility. & 0.840 \\
\hline DV3 & Respect and tolerance. & 0.754 \\
\hline DV4 & Commitment. & 0.821 \\
\hline RE1 & $\begin{array}{l}\text { Enables students to acquire practical } \\
\text { scientific knowledge in an objective } \\
\text { manner. }\end{array}$ & 0.650 \\
\hline RE2 & $\begin{array}{l}\text { Develops in students a commitment } \\
\text { to act for the society's and the } \\
\text { environment well-being. }\end{array}$ & 0.742 \\
\hline RE3 & $\begin{array}{l}\text { Enables students to debate societal } \\
\text { uncertainties and controversies. }\end{array}$ & 0.726 \\
\hline SE1 & Organised debates. & 0.638 \\
\hline SE2 & Problem situations. & 0.461 \\
\hline SE3 & Brainstorming session. & 0.706 \\
\hline SE4 & Case study method. & 0.530 \\
\hline SE5 & Lecture. & 0.462 \\
\hline
\end{tabular}


Furthermore, the value of the Cronbach's alpha index of the dimension "Teaching methods" is 0.928 , which is excellent."

\subsubsection{Dimension "Teaching activities"}

The dimension "educational activities", which is composed of elements related to training programmes oriented towards SD and green jobs, is declared by the results of the following indices: The $\mathrm{KMO}$ index is 0.758 which is $>0.5$, the Bartlett's test of sphericity is significant since its value is $<0.005$ (Table 13).

The Chi-square is presented with 224.0914 and the ddl by 10 this fact which shows the existence of a good relationship between the different items that constitute globally this dimension.

Table 13: KMO index and Bartlett test for the dimension "Teaching activities"

\begin{tabular}{|c|l|r|}
\hline \multicolumn{2}{|c|}{$\begin{array}{c}\text { Kaiser-Meyer-Olkin index for measuring } \\
\text { sampling quality }\end{array}$} & 0.758 \\
\hline \multirow{2}{*}{$\begin{array}{c}\text { Bartlett's Test of } \\
\text { Sphericity }\end{array}$} & Chi-Two approx. & 224.094 \\
\cline { 2 - 3 } & Ddl & 10 \\
\cline { 2 - 3 } & Meaning & 0.000 \\
\hline
\end{tabular}

The results of the matrix of initial eigenvalues of the dimension "Teaching activities" show us that only the first component has a value greater than 1 , this factor alone represents $54.953 \%$ of the total variance.

Thus, the values of the 5 items of the dimension "Teaching activities" are between 0.537 and 0.842 , which give them an acceptable significance (Table 14).

Table 14 Matrix of components of the dimension "Teaching activities"

\begin{tabular}{|c|l|c|}
\hline & \multicolumn{1}{|c|}{ Ites } & $\begin{array}{c}\text { Compo } \\
\text { nent 1 }\end{array}$ \\
\hline AE1 & $\begin{array}{l}\text { Your institution has sustainability- } \\
\text { oriented courses }\end{array}$ & 0.842 \\
\hline AE2 & $\begin{array}{l}\text { Your institution develops orientation } \\
\text { programmes on sustainability (new } \\
\text { courses, new modules, seminar } \\
\text { courses) }\end{array}$ & 0.838 \\
\hline $\begin{array}{l}\text { Environmental and sustainability } \\
\text { activities should be initiated by the } \\
\text { students themselves; independently } \\
\text { of the departments, (lecturers, } \\
\text { management...) }\end{array}$ & 0.537 \\
\hline AE4 & $\begin{array}{l}\text { All students receive training on } \\
\text { sustainability issues }\end{array}$ & 0.588 \\
\hline AE5 & $\begin{array}{l}\text { Your institution develops training } \\
\text { programmes geared towards green } \\
\text { jobs }\end{array}$ & 0.838 \\
\hline
\end{tabular}

The value of Cronbach's Alpha is satisfactory at 0.783 (Table 15).
Table 15: Reliability statistics

\begin{tabular}{|c|c|c|}
\hline $\begin{array}{c}\text { Cronbach's } \\
\text { Alpha }\end{array}$ & $\begin{array}{c}\text { Cronbach's Alpha based } \\
\text { on standardized items }\end{array}$ & $\begin{array}{c}\text { Number of } \\
\text { elements }\end{array}$ \\
\hline 0.783 & 0.783 & 5 \\
\hline
\end{tabular}

When analyzing the table of item total statistics, we notice that if we eliminate item AE3, the Cronbach's alpha value index improves and is displayed as 0.800 (Table 16).

Table 16: Item total statistics

\begin{tabular}{|l|l|l|l|l|l|}
\hline & AE1 & AE2 & AE3 & AE4 & AE5 \\
\hline $\begin{array}{l}\text { Scale average } \\
\text { when an item is } \\
\text { deleted }\end{array}$ & 9.99 & 10.04 & 10.06 & 9.39 & 9.84 \\
\hline $\begin{array}{l}\text { Variance of the } \\
\text { scale when an } \\
\text { element is } \\
\text { deleted }\end{array}$ & 8.53 & 8.953 & 10.72 & 9.756 & 8.594 \\
\hline $\begin{array}{l}\text { Full correlation } \\
\text { of corrected } \\
\text { items }\end{array}$ & 0.677 & 0.677 & 0.363 & 0.413 & 0.696 \\
\hline $\begin{array}{l}\text { Square of the } \\
\text { multiple } \\
\text { correlations }\end{array}$ & 0.55 & 0.564 & 0.179 & 0.259 & 0.518 \\
\hline $\begin{array}{l}\text { Cronbach's } \\
\text { Alpha when the } \\
\text { item is deleted }\end{array}$ & 0.7 & 0.704 & 0.8 & 0.794 & 0.695 \\
\hline
\end{tabular}

Thus the dimension "Teaching activities" is composed of the following items: AE1, AE2, AE3 and AE5. Following the parameters relating to training, we have deployed the same indexes in order to measure SD practices, which we present in the approach below:

\subsection{Sustainable development practices}

We have measured the adequacy of the sampling which shows that the KMO index is 0,651 (Table 17). It is qualified as acceptable. This index reveals that the correlations between the items of this variable are of good quality.

Table 17: KMO index and Bartlett's test for the variable "SD practices"

\begin{tabular}{|l|l|r|}
\hline \multicolumn{2}{|c|}{$\begin{array}{c}\text { Kaiser-Meyer-Olkin index for sampling } \\
\text { quality measuring. }\end{array}$} & 0.682 \\
\hline \multirow{3}{*}{ Bartlett's Test of Sphericity } & Chi-two approx & 238.830 \\
\cline { 2 - 3 } & Ddl & 45 \\
\cline { 2 - 3 } & Meaning & 0.000 \\
\hline
\end{tabular}

Table 18 shows that the first three factors have higher total values than the rest of the components of this variable. The first component accounts for $36.973 \%$ of the total variance of the analysis, the second for $15.231 \%$ and the third for $10.647 \%$. 
Table 18: Total explained variance of the variable "SD practices".

\begin{tabular}{|c|c|c|c|c|}
\hline \multicolumn{2}{|c|}{ Component } & $\mathbf{1}$ & $\mathbf{2}$ & $\mathbf{3}$ \\
\hline \multirow{2}{*}{$\begin{array}{c}\text { Initial } \\
\text { Eigen } \\
\text { values }\end{array}$} & $\begin{array}{c}\text { Total } \\
\text { variance }\end{array}$ & 3.697 & 1.523 & 1.065 \\
\cline { 2 - 5 } & $\begin{array}{c}\% \\
\text { Cumulated }\end{array}$ & 36.973 & 15.23 & 10.65 \\
\hline \multirow{2}{*}{$\begin{array}{c}\text { Sums } \\
\text { extracted } \\
\text { from the } \\
\text { load } \\
\text { square }\end{array}$} & $\begin{array}{c}\text { Total } \\
\text { variance }\end{array}$ & 3.697 & 52.2 & 62.85 \\
\cline { 2 - 5 } & $\begin{array}{c}\% \\
\text { Cumulated }\end{array}$ & 36.973 & 15.23 & 1.065 \\
\hline
\end{tabular}

In order to choose the number of factors to be extracted, the graph of the eigenvalues, where the break of the Cattell's bend is located, reveals an abrupt change after the 1st facto. Hence, we retain this last one for the analysis, since it is more rigorous than that of the eigenvalues. Table 19 reveals that only 8 items have values between 0.484 and 0.842 , which gives them acceptable significance. The value of Cronbach's alpha index is 0.820 , close to 1 . Hence, we can state that all the elements of the SD practices are homogeneous.

Table 19: Matrix of components of the "Sustainable development practices "variable"

\begin{tabular}{|c|c|c|}
\hline & Items & $\begin{array}{c}\text { Component } \\
1\end{array}$ \\
\hline IDD2 & $\begin{array}{l}\text { To employability requirements } \\
\text { (ease of job market integration } \\
\text { of university graduates) }\end{array}$ & 0.609 \\
\hline IDD3 & $\begin{array}{l}\text { To the requirements of the } \\
\text { economic } \\
\text { (establishment activity } \\
\text { multinationals at regional level) }\end{array}$ & 0.622 \\
\hline ADD1 & $\begin{array}{l}\text { amp community commitment } \\
\text { by your institution, including } \\
\text { faculty, to sustainable } \\
\text { development practices and } \\
\text { promotion }\end{array}$ & 0.756 \\
\hline ADD2 & $\begin{array}{l}\text { A community commitment } \\
\text { from your institution including } \\
\text { the administration to } \\
\text { sustainable development } \\
\text { practices and promotion }\end{array}$ & 0.728 \\
\hline ADD3 & $\begin{array}{l}\text { Community commitment of } \\
\text { your institution, including } \\
\text { students, in sustainable } \\
\text { development practices and } \\
\text { promotion }\end{array}$ & 0.843 \\
\hline ADD4 & $\begin{array}{l}\text { Prise en compte de la } \\
\text { planification des actions envers } \\
\text { le DD (ex. Consideration of SD } \\
\text { action planning (e.g. } \\
\text { celebration of environment } \\
\text { days, SD week, meeting with }\end{array}$ & 0.612 \\
\hline
\end{tabular}

\begin{tabular}{|c|l|c|}
\hline & \multicolumn{1}{|c|}{ Items } & $\begin{array}{c}\text { Component } \\
\mathbf{1}\end{array}$ \\
\hline ADD5 & $\begin{array}{l}\text { professionals, experts, quality } \\
\text { of life }\end{array}$ & $\begin{array}{l}\text { The existence of a steering } \\
\text { group (SD committee or cell) at } \\
\text { your institution's level }\end{array}$ \\
\hline ADD6 & $\begin{array}{l}\text { Your institution has a student } \\
\text { association or club with an SD } \\
\text { vocation }\end{array}$ & 0.619 \\
\hline
\end{tabular}

\section{Hypotheses validation}

Once our results analyzed, we proceed to the validation of our study theoretical model hypotheses which we recall below:

H1: The curriculum has a significant effect on SD practices.

H2: Pedagogical approaches have a significant effect on SD practices.

H3: The more diversified the pedagogical methods are, the more they impact sustainable development practices.

H4: Teaching activities have a direct impact on SD practices.

Consequently, our conceptual model that has to be tested is presented as follows.

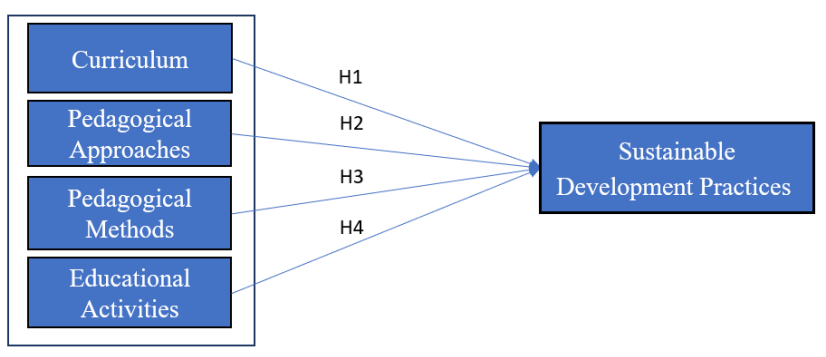

Fig. 3: Training with 4 dimensions

The results of the ANOVA analysis are reported as follows. According to table 20 below, we have a single model and the correlation coefficient between the explanatory variables and the variable to be explained $\mathrm{Y}=0.637$; the $\mathrm{R}$ square is 0.405 . This model explains $40.5 \%$ of the variance in sustainable development practices.

Table 20: Summary of models

\begin{tabular}{|c|c|c|c|c|}
\hline Model & R & $\begin{array}{c}\text { R- } \\
\text { Two }\end{array}$ & $\begin{array}{c}\text { R-Two } \\
\text { adjusted }\end{array}$ & $\begin{array}{c}\text { Standard error of } \\
\text { the estimation }\end{array}$ \\
\hline 1 & 0.636 & 0.404 & 0.385 & 0.54229 \\
\hline
\end{tabular}

Furthermore, by proceeding with the ANOVA analysis of variance (Table 21), we find that the significance of the model tested is less than 0.05 since its value is equal to 0.000 . Consequently, we declare that there is no link between the variables to be rejected and we judge the model as good overall. 
Table 21: Summary of ANOVA models

\begin{tabular}{|l|l|l|l|l|l|}
\hline Model 1 & $\begin{array}{c}\text { Sum of } \\
\text { squares }\end{array}$ & ddl & $\begin{array}{c}\text { Mediu } \\
\mathbf{m} \\
\text { square }\end{array}$ & F & Sig. \\
\hline Regression & 25.712 & 4 & 6.428 & 21.859 & 0.000 \\
\hline Residue & 37.936 & 129 & 0.294 & & \\
\hline Total & 63.648 & 133 & & & \\
\hline
\end{tabular}

With regard to the coefficients' table, we remark the significance of the different variables (curriculum, pedagogical approaches and pedagogical methods) except for the teaching activity which presents a value of 0.280 above the 0.05 threshold (Table 22). Dealing with collinearity, the values of the tolerance of the different variables are higher than the threshold 0.3 , in the same way for the VIF, the value of the different variables are lower than 4. Thus, the regression equation is expressed as follows:

$$
\mathrm{Y}=0.835+0.318 * \mathrm{Cu}+0.431 * \mathrm{PA}+-0.308 * \mathrm{PM}+0.072 * \mathrm{TA}
$$

With :

$\mathrm{Cu}=$ Curriculum, $\quad \mathrm{PA}=$ Pedagogical approaches, $\mathrm{PM}=$ Pedagogical methods and $\mathrm{TA}=$ Teaching activities

Table 22: Coefficients table

\begin{tabular}{|c|c|c|c|c|c|}
\hline \multirow[t]{2}{*}{ Model 1} & $\begin{array}{c}\text { Stand } \\
\text { ardize } \\
\text { d } \\
\text { coeffic } \\
\text { ients } \\
\end{array}$ & & & \multicolumn{2}{|c|}{$\begin{array}{c}\text { Co-linearity } \\
\text { statistics }\end{array}$} \\
\hline & B & $\mathbf{T}$ & Sig & $\begin{array}{c}\text { Tolera } \\
\text { nce }\end{array}$ & VIF \\
\hline Constant & 0.835 & 4.076 & 0.000 & & \\
\hline Curriculum & 0.318 & 4.439 & 0.000 & 0.665 & 1.504 \\
\hline $\begin{array}{l}\text { Pedagogical } \\
\text { approaches }\end{array}$ & 0.431 & 4.883 & 0.000 & 0.534 & 1.873 \\
\hline $\begin{array}{l}\text { Pedagogical } \\
\text { Methods }\end{array}$ & -0.308 & -2.783 & 0.006 & 0.546 & 1.830 \\
\hline $\begin{array}{l}\text { Teaching } \\
\text { Activities }\end{array}$ & 0.072 & 1.084 & 0.280 & 0.757 & 1.321 \\
\hline
\end{tabular}

Following the results announced above, we specify that the teaching activities ( significance $=0.280$ ) will not be included in the explanation of sustainable development practices, which forces us to recalculate the regression of these. Table 23 presents the results of the coefficients of the different variables and their significance.

Table 23: Coefficients results

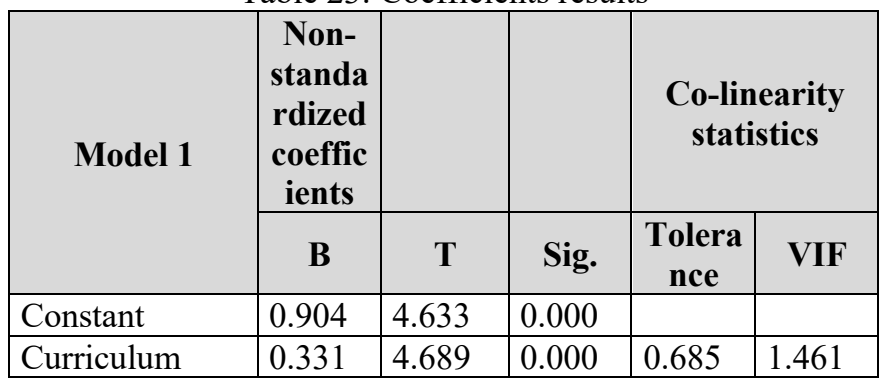

\begin{tabular}{|l|l|l|l|l|l|}
\hline $\begin{array}{l}\text { Pedagogical } \\
\text { approaches }\end{array}$ & 0.427 & 4.845 & 0.000 & 0.534 & 1.871 \\
\hline $\begin{array}{l}\text { Pedagogical } \\
\text { Methods }\end{array}$ & -0.265 & -2.564 & 0.011 & 0.624 & 1.602 \\
\hline
\end{tabular}

The new regression equation is displayed in this manner:

$\mathrm{Y}=0.904+0.331 * \mathrm{Cu}+0.427 * \mathrm{TA}+-0.265 * \mathrm{TM}$

With: $\mathrm{Cu}=\mathrm{Curriculum}, \mathrm{TA}=$ Teaching approaches and $\mathrm{TM}=$ Teaching methods

Ultimately, the new conceptual model is presented in the figure below:

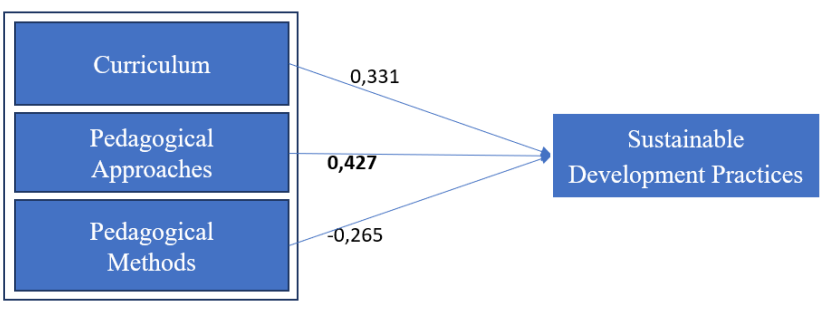

Fig. 4: Training with 3 dimensions

\section{Conclusion}

The aim of this article is to evaluate the impact of training on SD practices at the ITUK (Morocco). Consequently, and according the different results discussed above, the SD integration level in training varies considerably from one university teacher to another and from one institution to another.

We have confirmation of hypothesis 2, which stipulates that pedagogical approaches operate significant effects on SD practices, which is in line with the Higher Education Strategic Vision 20152030 Reform. In this respect, the Higher Council of Education and Scientific Research recommends "The diversification and appropriate choice of these approaches, both at the level of the initial training of educational actors and at the level of teaching, learning and training practices and situations"[2]. These pedagogical approaches are organically linked to the implementation of curricula, programs and training.

Equally, the pedagogical approaches constitute the reference framework underlying the management of teaching acts and learning steering. Therefore, we notice the considerable weight of pedagogical approaches (0.427), which are more important than that of the curriculum and teaching methods. In fact, the informed university teachers are solicited to work more on pedagogical approaches if they wish to succeed in their teaching actions, mission and involvement within this educational locomotive frame. 
Indeed, many researches conducted by the scientists emphasize the fact that education plays a crucial role at the level of social and individual prosperity [27].

In this regard, the guidelines of the Higher Education Strategic Vision 2015-2030 Reform give a lot of importance to these approaches, as well as their diversification, both at the level of initial training of educational actors, and at the level of practices and situations of teaching, learning and training. Also, the pedagogical approach allows itself to promote the knowledge self-construction, by opening up to interactive methods that encourage students to take the initiative and engage themselves in scientific and practical activities.

Accordingly, the University is invited to develop a reference framework relating to pedagogical approaches that would govern teaching practices with the aim of achieving the objectives of SD in a collective manner [18] as these approaches, when mobilized in teaching, are the development of students' skills, such as objective-based teaching, learning-by-doing and pedagogy by objectives, project pedagogy or discovery and problem-solving pedagogy.

In terms of the effects of training on SD practices, this study will enable higher education actors to draw the necessary conclusions for the development of curricula, programs and training through approaches and methods that must remain in conformity with the major societal, social and environmental choices. A good pedagogical model promotes openness to innovations, knowledge, culture and universal values.

Higher education institutions must direct the construction of curricula by integrating pedagogical approaches. This can be achieved by offering more training to teachers who intervene as the sole actors in this learning action through their knowledge transmission, know-how and know-being.

In its new development model for 2035, the Moroccan university must operate with a deep modernization of its programs and pedagogical approaches [2]

The university curriculum must be irrigated by several approaches and must emphasize soft skills: Study Skills, Life Skills, Civic Skills and Professional Skill, in particular emphasizing projectbased learning, teamwork, critical thinking, etc.

The transition to digital technology through MOOCs as a pedagogical support for online training is a powerful lever for development, transformation and pedagogical innovation, which will allow for interactive, experiential and transformative learning that will only be beneficial for the acquisition of all the practices related to $\mathrm{SD}$ for the next generation [28].

In any case, the university has a moral duty to work toward a SD society for present and future generations, as it is the fundamental core where the different tomorrow's leaders skills are forged. Each higher education institution should have a crystalclear vision to ensure a contribution to a sustainable society through the training it provides (curricula, teaching approaches and methods applied

\section{References}

[1] Vision stratégique de la réforme : pour une école de l'équité, de la qualité et de la promotion, Conseil Supérieur de l'Éducation, de la Formation et de la Recherche Scientifique, Dec. 2020.

[2] La commission sur le modèle de développement, Le nouveau modèle de développement, 170, 2021.

[3] Haut Commisariat au plan, Le Maroc entre Objectifs du Millénaire pour le Développement et Objectifs de Développement Durable _ Les acquis et les défis, National, 2015.

[4] R. Jarkovsky, S. Major, P. Cyrus, "The 3DPrint in Technical Education and Creativity Development," 14, 6, 2018.

[5] R. Lozano, M. Merrill, K. Sammalisto, K. Ceulemans, F. Lozano, "Connecting Competences and Pedagogical Approaches for Sustainable Development in Higher Education: A Literature Review and Framework Proposal," Sustainability, 9(10), 1889, 2017, doi:10.3390/su9101889.

[6] W.J. Bakhella, Perceptions et pratiques relatives à l'Éducation au Développement Durable au Maroc : Le Cas de l'Université Mohammed V de Rabat, Université Mohammed V de Rabat, Rabat, Morocco, 2017.

[7] High Planning Commission, VOLUNTARY NATIONAL REVIEW OF THE IMPLEMENTATION OF THE SUSTAINABLE DEVELOPMENT GOALS, National, 188, 2020.

[8] Impact Rankings 2021: clean water and sanitation (SDG 6) methodology, Times Higher Education (THE), 2021.

[9] Impact Rankings 2021: affordable and clean energy (SDG 7) methodology, Times Higher Education (THE), 2021. 
[10] Déclaration mondiale sur l'éducation pour tous - 1990 - Texte intégral, Humanium, May 2021.

[11] https://plus.google.com/+UNESCO, Africa joins the global community to promote ESD for 2030, UNESCO, 2021.

[12] Aichi-Nagoya Declaration on Education for Sustaina | Department of Economic and Social Affairs, May 2021.

[13] Declaration on higher education for sustainability, University World News, Jun. 2021.

[14] W. Lambrechts, H. Van den Haute, I. Vanhoren, Duurzaam hoger onderwijs. Appel voor verantwoord onderrichten, onderzoeken en ondernemen. [Sustainable Higher Education. Appeal for Responsible Education, Research and Operations], LannooCampus; Leuven, 2009.

[15] R.A. Ramirez-Mendoza, R. MoralesMenendez, E.M. Melchor-Martinez, H.M.N. Iqbal, L. Parra-Arroyo, A. Vargas-Martínez, R. Parra-Saldivar, "Incorporating the sustainable development goals in engineering education," International Journal on Interactive Design and Manufacturing (IJIDeM), 14(3), 739-745, 2020, doi:10.1007/s12008-020-00661-0.

[16] J. Gosling-Goldsmith, SUSTAINABLE DEVELOPMENT GOALS AND UNCERTAINTY VISUALIZATION, 2018.

[17] T. Zhai, Y.-C. Chang, "Standing of Environmental Public-Interest Litigants in China: Evolution, Obstacles and Solutions," Journal of Environmental Law, 30(3), 369-397, 2018, doi:10.1093/jel/eqy011.

[18] G.H. Brundtland, Notre avenir à tous, Oslo: 349, 1987.

[19] T. Zhai, Y.-C. Chang, "The Contribution of China's Civil Law to Sustainable Development: Progress and Prospects," Sustainability, 11(1), 294, 2019, doi:10.3390/su11010294.

[20] A. Diemer, "L'éducation au développement durable, une affaire de représentation," Revue francophone du développement durable, (1), 30, 2013.

[21] PDU - Smart Campus, Université Ibn Tofail, Jun. 2021

[22] M. Yarime, Y. Tanaka, "The Issues and Methodologies in Sustainability Assessment Tools for Higher Education Institutions: A
Review of Recent Trends and Future Challenges," Journal of Education for Sustainable Development, 6(1), 63-77, 2012, doi:10.1177/097340821100600113.

[23] É. VERNETTE, "L'efficacité des instruments d'études : évaluation des échelles de mesure," Recherche et Applications En Marketing, 6(2), 43-65, 1991.

[24] V. Eric, Techniques d'étude de marché - Eric Vernette - 4ème édition - Librairie Eyrolles, 2018.

[25] Yves Evrard, P. Bernard, R. Elyette, Market - Fondements et méthodes des recherches en marketing -... - Librairie Eyrolles, Jun. 2021.

[26] P. Roussel, F. Wacheux, Management des ressources humaines : méthodes de recherche en sciences humaines et sociales / sous la direction de Patrice Roussel et Frédéric Wacheux, de Boeck. Bruxelles, 2005.

[27] H. Kotina, M. Stepura, V. Fedosov, D. Hrysohlazov, M. Bilinets, "Competitiveness of Higher Education in Ukraine and Certain EuropeanCountries: Empirical Studies on Funding and Academic Attractiveness," WSEAS TRANSACTIONS ON BUSINESS AND ECONOMICS, 17, 849-858, 2020, doi:10.37394/23207.2020.17.83.

[28] K. Brundiers, A. Wiek, C.L. Redman, "Realworld learning opportunities in sustainability: from classroom into the real world," International Journal of Sustainability in Higher Education, 11(4), 308-324, 2010, doi:10.1108/14676371011077540.

\section{Creative Commons Attribution License 4.0 (Attribution 4.0 International, CC BY 4.0)}

This article is published under the terms of the Creative Commons Attribution License 4.0 https://creativecommons.org/licenses/by/4.0/deed.en $\underline{\text { US }}$ 